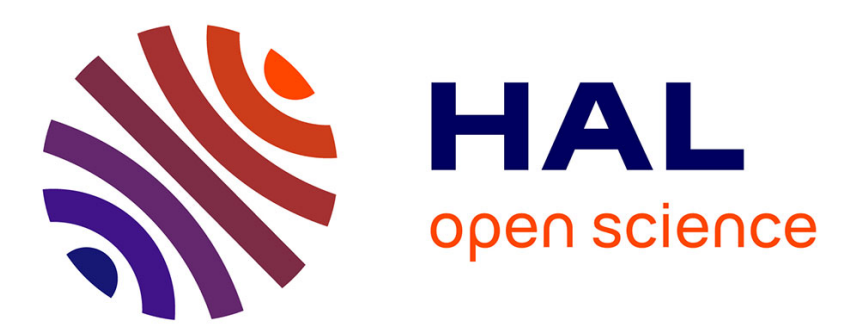

\title{
Image and venue as factors mediating latent spillover pressure for agenda-setting change
}

Paul Stephenson

\section{To cite this version:}

Paul Stephenson. Image and venue as factors mediating latent spillover pressure for agenda-setting change. Journal of European Public Policy, 2012, 19 (6), pp.796-816. 10.1080/13501763.2011.614141. hal-01024524

\section{HAL Id: hal-01024524 \\ https://hal-sciencespo.archives-ouvertes.fr/hal-01024524}

Submitted on 16 Jul 2014

HAL is a multi-disciplinary open access archive for the deposit and dissemination of scientific research documents, whether they are published or not. The documents may come from teaching and research institutions in France or abroad, or from public or private research centers.
L'archive ouverte pluridisciplinaire HAL, est destinée au dépôt et à la diffusion de documents scientifiques de niveau recherche, publiés ou non, émanant des établissements d'enseignement et de recherche français ou étrangers, des laboratoires publics ou privés. 
This article was downloaded by: [FNSP Fondation National des Sciences Politiques]

On: 16 July 2014, At: 02:55

Publisher: Routledge

Informa Ltd Registered in England and Wales Registered Number: 1072954

Registered office: Mortimer House, 37-41 Mortimer Street, London W1T 3J H, UK

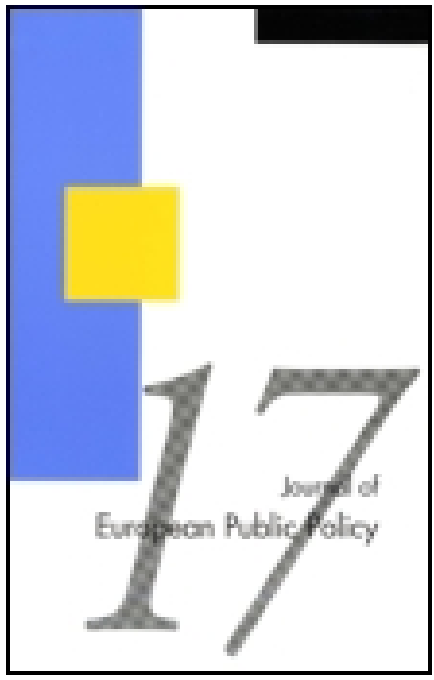

\section{J ournal of European Public Policy}

Publication details, including instructions for authors and subscription information:

http:/ / www. tandfonline.com/ loi/ rjpp20

\section{Image and venue as factors mediating latent spillover pressure for agenda-setting change}

Paul J. Stephenson

Published online: 20 Sep 2011.

To cite this article: Paul J. Stephenson (2012) Image and venue as factors mediating latent spillover pressure for agenda-setting change, J ournal of European Public Policy, 19:6, 796-816, DOI: 10.1080/ 13501763.2011.614141

To link to this article: http:// dx. doi.org/ 10.1080/ 13501763.2011.614141

\section{PLEASE SCROLL DOWN FOR ARTICLE}

Taylor \& Francis makes every effort to ensure the accuracy of all the information (the "Content") contained in the publications on our platform. However, Taylor $\&$ Francis, our agents, and our licensors make no representations or warranties whatsoever as to the accuracy, completeness, or suitability for any purpose of the Content. Any opinions and views expressed in this publication are the opinions and views of the authors, and are not the views of or endorsed by Taylor $\&$ Francis. The accuracy of the Content should not be relied upon and should be independently verified with primary sources of information. Taylor and Francis shall not be liable for any losses, actions, claims, proceedings, demands, costs, expenses, damages, and other liabilities whatsoever or howsoever caused arising directly or indirectly in connection with, in relation to or arising out of the use of the Content.

This article may be used for research, teaching, and private study purposes. Any substantial or systematic reproduction, redistribution, reselling, loan, sublicensing, systematic supply, or distribution in any form to anyone is expressly 
forbidden. Terms \& Conditions of access and use can be found at http:// www.tandfonline.com/page/terms-and-conditions 


\title{
Image and venue as factors mediating latent spillover pressure for agenda-setting change
}

\author{
Paul J. Stephenson
}

\begin{abstract}
Agenda-setting in the EU has been largely approached using literature from US scholars that emerged over the last 35 years. Surprisingly perhaps, grand theory in European integration has been ignored, even though it might offer valuable insights for longitudinal studies, particularly where issues have had difficulty making it onto the policy agenda. This article seeks to reconcile neofunctionalist and agenda-setting literature, to trace the journey towards agenda-setting, a process through which venues and images play a crucial role over time in framing competing issues. It puts forward a combined framework for analysing agendasetting dynamics, before applying it to examine a policy case over five decades. Tracing the 'issue career' of Community rail infrastructure upwards onto the EU's policy agenda, it shows how strategies to gain attention and build credibility mediate latent spillover pressures in order to secure agenda-setting change.
\end{abstract}

KEY WORDS Agenda-setting; image; neofunctionalism; rail transport; spillover; venue.

\section{INTRODUCTION}

Some 35 years of agenda-setting literature from American scholars of public policy have provided the concepts of 'policy streams' and 'windows of opportunity' (Kingdon 1984), the importance of 'policy images' and 'institutional venues' (Baumgartner and Jones 1991, 1993, 2002) and the notion of 'issue careers' (Cobb et al. 1976). The literature which is applied to EU policymaking is, however, in its relative infancy. Significant research has been made in the last five years by scholars of the EU with policy cases on bioterrorism, anti-smoking policy, health care, alcoholism and fisheries, seeking to account for the forces at play in influencing the degree of attention that issues receive (Princen 2007, 2009, 2010, 2011; Princen and Rhinard 2006). Despite Peters' (1996) and Pollack's (1997) contributions to the debate on agendasetting, the literature is scant compared with EU decision-making.

It seems odd that little regard has been given to grand theory when analysing agenda-setting in common policy-making. Theoretical approaches to agendasetting in EU policy analysis have ignored neofunctionalism (Haas 1958, 
1975; Lindberg 1963). This may simply be because it was considered defunct when US public policy scholars worked on agenda-setting. More likely, however, American public policy scholars who initiated the agenda-setting literature were looking at US politics, not the EC. Arguably, neofunctionalism was considered useful for trying to explain the dynamics of the regional integration process and institution building, but ignored as a tool for actual policy analysis.

Neofunctionalism is highly relevant to the study of agenda-setting in the EU, after all 'integration' is nothing more than the cumulative build-up of successful agenda-setting at the supranational level - the composite of thousands of issues being consecutively and - often in parallel - propelled onto the table of policymakers, to be later decided upon. Various types of pressure influence the direction of the policy agenda, yet by itself, spillover fails to account for what actually determines attention-shift in agendas. Pressure for spillover builds up, but needs to be triggered; it is thus latent - concealed, inactive, lying dormant or hidden until circumstances are suitable for its manifestation, or 'release'. These circumstances may depend on venues and images (frames) used by policy actors in their attempt to 'sculpt' an issue to help it reach the policy agenda; these factors may 'mediate' (or encourage) the release of spillover pressures.

This article proposes to make a key theoretical point by reconciling the two sets of literature from integration theory and public policy. It seeks to identify how venue and image might articulate spillover pressures, enabling an issue through several 'career stages' - to journey up the political agenda. Equally, it shows how venue and image strategies may be unconvincing, and why, despite the build up of certain pressures, spillover may not occur. While spillover is the key focus here, the case touches upon other neofunctionalist considerations such as automacity and politicization.

With the issue of co-ordinated European rail transport as a longitudinal case study over 50 years, the article analyses how an issue can struggle for attention over time. Rail transport would seem a highly likely case for early integration, both because transport policy was included in the Treaty of Rome (along with agriculture) and because - given the EU's beginnings with coal and steel - one would expect rail transport to have been a prime sector subject to spillover effects from integration efforts elsewhere. Peterson (1991: 274) asserts the case for functional spillover in that, 'common policies in highly technical, non-controversial sectors would require common policies in other areas due to technical pressures'. The convergence of political perceptions would produce policy inducing a more complex pattern of trans-national sectoral activity. Why, then, did it take so long for a European rail policy with the co-ordinated planning of infrastructures to develop? One might argue that the case is an example of chronic agenda-setting failure come good, demonstrating how the development of common infrastructures and an interoperable European rail network was constrained by a staid and highly technical EC transport policy, only making progress thanks to the configuration of authoritative venues and convincing images at a later stage. 
The second section of this article considers the classic theoretical literature into agenda-setting to date, to see how European integration theory may actually compliment the public policy concepts (and vice versa), to allow for a more nuanced understanding of agenda-setting dynamics. The third section builds a refined framework for analysing agenda-setting over time. The fourth section then uses it to analyse the case of European railways over five decades, to examine what the case can tell us about venue and image vis-à-vis spillover, and our understanding of the dynamics behind agenda-setting change.

\section{RECONCILING THEORETICAL INSIGHTS INTO AGENDA- SETTING}

\section{European public policy}

\section{Issue careers}

Why certain issues end up as topics for European Union policy-making, while others do not, is uncertain (Princen and Rhinard 2006). What makes a 'concern' legitimate enough for it to be recognized as an 'issue' that warrants policy action at the supranational level? Many proposals are floated but only a small proportion makes it high up the political agenda, influenced by the political climate or 'events'. A whole set of political and non-political factors may account for the rise and fall of issues - a process during which policy actors form coalitions, which in turn frame issues; they are never just 'on' or 'off the agenda, but receive little, some, or lots of attention (Princen 2007: 23). Downs (1972) refers to 'issue-attention cycles'. Kingdon (1984) distinguishes between 'governmental agendas' issues that receive attention, and 'decision agendas' where political action must be taken. An issue's 'agenda-setting attributes' may help explain shifts in attention and policy responses (Green-Pedersen and Wilkerson 2006: 1040). Cobb et al. (1976) distinguish between three types of agenda dynamics, depending on where an issue emanates from, and how it becomes relevant to other agendas: in the 'outside initiative' external issues become political and are set on the 'formal' agenda; in the 'mobilization model' political initiators try to sell an issue to a wider public; and with 'inside access' issues born of internal decision-makers never actually make it outside (Princen and Rhinard 2006: 1120). Caporaso and Keeler (1995) distinguish between 'high politics' issues dictated from above, and 'low politics' issues fed upwards.

How to conceive of issue development over time? Hogwood and Gunn (1984) refer to the three stages of issue 'search', 'filtration' and 'definition', while Cobb et al. (1976) recognize four stages in an issue's career. 'initiation', 'specification', 'expansion' and 'entrance'. An issue may be 'initiated' as high politics by being placed on an agenda by a top official, but interest may wane or the issue's urgency go unrecognized. Thereafter, it may be left to low-level officials to 'specify' the issue over many years, hammering out technical elements. An issue may 'expand' by travelling up slowly to higher political levels, only 'entering' once it has gained access to the formal agenda. A low 
politics route implies a long-term, incremental and self-sustaining dynamic whereby there is, suddenly, no ignoring the issue - a 'point of no return' (Princen and Rhinard 2006: 1122).

\section{Timing and sequence}

Time, planning and policy-making form a complex triangular relationship (Schneider 1991). One should not conceive of agenda-setting as a phenomenon that occurs over night, but over an extended time period. Kingdon (1984) asserts that actor participation varies in different issue areas over time and depends on a convergence of multiple elements (problems, policies and politics), each with its own dynamics. Long time frames help explain the 'rise and fall' of issues and the 'punctuated' way in which policy-making proceeds (Pralle 2006: 987). Jolts to the process, in the form of external shocks, such as a 'focusing event', including a crisis or disaster, bring about shifts in authority, or the mobilization of new interests to an issue (Pralle 2006: 989); pushing an issue up the agenda depends on how well interests and institutions are organized, the balance of power and distribution of resources, plus the ability to secure interest in it.

Timing provides strategic opportunities to 'venue shop' - to identify an ambitious or empowered institution where the issue can be 'homed', nurtured, groomed, i.e. a place where politicians and interests groups are sympathetic or disposed to the issue, perhaps who harbour an ambitious political vision, or are promoting a programme that can 'accommodate' it. As Princen (2007: 12) points out, a key feature of the focus on venues is that it enables one to look for moments of 'issue internationalization', i.e. where national collective action problems can become international (Community) ones.

\section{Images and venues}

Baumgartner and Jones' (1991, 1993, 2002) theory of 'venue shopping' was built on the premise that policy change is secured when policy actors are able to shift debates and decisions on an issue to new or modified venues, which enables the issue to be approached from different angles; the original venue may have effectively monopolized how it was treated politically, even straight-jacketing it to prevent agenda-setting change. In the EU issues are discussed by many institutions and organizations at the supranational level, but few (Council and EP) have the prerogative of decision-making. Image is crucial, not only in the media, but for attention-shift politics and policy-making. As Baumgartner and Jones (1993: 25) assert, 'policy images play a critical role in the expansion of issues to the previously apathetic [policy actors and institutions]'. Specialists (as opposed to generalists) choose ways to communicate the issue in simplified and symbolic terms. The images chosen to refer to the issue will depend on the favoured policy focus; the issue will be 'given' certain social and political implications, though not all policy actors will recognize or agree with them. Thus, with policy images made up of a blend of empirical information and emotive/evaluative appeals (both subtle and strong) 'tone' can critically determine how an issue develops (Baumgartner and Jones 1993: 26). The 
dynamics of (incremental or rapid) change depends on the strategies employed by political, social, business or media 'image-makers', who largely determine how and when the issue is received by policy-makers. Figure 1 consolidates various typologies concerning strategy, as recently developed by Princen (2011), after Baumgartner and Jones (1993), to show what we seek to identify when examining venues and images up close, and how they are used to gain attention and build credibility.

\section{European integration studies}

\section{Grand theory}

Given that the Commission has long been the official agenda-setter, it seems highly logical to consider neofunctionalism when examining agenda-setting change, particularly concerning the incremental and concerted activity of supranational elites, even if they do not operate in a vacuum; the agenda-setting process brings in many more communities of actors (Princen 2007: 23). Incremental decision-taking (over grand designs) results from the unintended consequences of the policy process; precisely, what the functionalists termed 'latent' as opposed to 'manifest' outcomes. As Haas (1970: 627) later argued, political actors are incapable of long-range purposive behaviour, stumbling from one decision to the next, with imperfect knowledge of the consequences and up

\begin{tabular}{|c|c|c|}
\hline & Venue & Image \\
\hline $\begin{array}{l}\text { Gaining } \\
\text { Attention } \\
\text { to the } \\
\text { issue }\end{array}$ & $\begin{array}{l}\text { Strategies for } \\
\text { Mobilising Support } \\
\text { 1. Venue shopping horizontally (EU } \\
\text { level across the public institutions } \\
\text { but also private organizations) } \\
\text { 2. Venue shopping vertically } \\
\text { (international/global, national, } \\
\text { subnational level; including civil } \\
\text { society and business groups) } \\
\text { 3. Creating new venues (setting up } \\
\text { agencies, fostering lobbies) } \\
\text { 4. Changing existing institutional } \\
\text { frameworks (instigating internal } \\
\text { reorganization, shifting focus) }\end{array}$ & $\begin{array}{l}\text { Strategies for } \\
\text { Arousing Interest } \\
\text { 1. Big words (appealing to } \\
\text { fundamental norms and values; } \\
\text { tying in with stated policy } \\
\text { priorities; associating symbols; } \\
\text { using persuasive language, } \\
\text { rhetoric, narrative) } \\
\text { 2. Small steps (doing studies; } \\
\text { organizing conferences; focusing } \\
\text { on non-controversial elements; } \\
\text { targeting communications to } \\
\text { specific groups; involving key } \\
\text { political figures) }\end{array}$ \\
\hline $\begin{array}{l}\text { Securing } \\
\text { Credibility } \\
\text { of the } \\
\text { issue }\end{array}$ & $\begin{array}{l}\text { Strategies for } \\
\text { Building Capacity } \\
\text { 1. Inside the EU institutions } \\
\text { (seconding national experts to the } \\
\text { Commission; creating intergroups } \\
\text { in EP; targeting EP committees; } \\
\text { referring cases to the ECJ; using } \\
\text { advisory bodies as back-up) } \\
\text { 2. Outside the EU institutions } \\
\text { (subsidizing interest groups; } \\
\text { consulting networks of experts; } \\
\text { exchanging best practice) }\end{array}$ & $\begin{array}{l}\text { Strategies for } \\
\text { Claiming Authority } \\
\text { 1. Establishing links with existing } \\
\text { policies (highlighting the link to a } \\
\text { grand vision or medium-term } \\
\text { goal; 'economicizing' the issue) } \\
\text { 2. Identifying common ground } \\
\text { (identifying widespread } \\
\text { challenges; defining a European } \\
\text { model; purporting expertise and } \\
\text { knowledge; using data and } \\
\text { statistics; projecting scenarios) }\end{array}$ \\
\hline
\end{tabular}

Figure 1 Venue and image strategies in the EU

Source: After Princen (2009, 2011) 
against deadlines. Second, institutional venues comprise technocrats who facilitate - or 'engineer' - the (re)framing of an issue previously low on the agenda, by matching it with one receiving greater attention, thus advocating which issues merit political attention. Third, venues from horizontal and vertical linkages vary in their institutional power dynamics over time, certainly at the supranational level. Systemic variables such as power distribution, informational asymmetry, leadership strength and consensus, all affect the collective ability of elites to find common ground or reach compromise. Lindberg $(1963,1965)$ recognized the value of a shared body of ideas acting as political glue, binding elites to invest in integration, while Haas (1958) argued that EC membership transformed interest group and government perceptions of the national interest. Fourth, integration is accelerated in areas where scientists and technicians play a key role (Farrell and Héritier 2005: 275) - and in rail transport, developing common technology, management and safety specifications is central to policy integration.

\section{Spillover}

Central to neofuntionalist predictions was the principle of 'spillover' or 'engrenage'. Policy integration would intensify and expand through the policy process, arising from a number of causal variables: political spillover (the exertion of integrative pressures by national elites and the socialization of national civil servants at a supranational level), functional spillover (the assurance of original goals through further integrative action) and cultivated spillover (the exertion of integrative pressures by Community institutions, be it through institutional self-interest). Spillover was seen as a dynamic of integration, driven by learning processes, credible commitments and the creative cultivation of interests, themselves evolving through a process of issue framing inside and between institutional venues.

For spillover to occur, Haas (1958) believed issues need to be first depoliticized and characterized by pragmatic interest politics, while Schmitter (1969, 1970) held that politicization was in fact the necessary driving force since the controversy of joint-decision-making would attract wider groups. A decade after Haas, Schmitter (1969: 1962) already observed how the process of integration was equally driven by frustration and/or dissatisfaction in the attainment of collectively agreed goals (perhaps due precisely to the failure of pragmatic interest politics), which actually pushed elites to collaborate in relating sectors or find new ways to secure intensified commitment in the existing sectors.

As Niemann and Schmitter (2009: 56) assert, functional spillover depends on perceptions. Actors must believe that 'functional structure' - i.e. the configuration and qualification of policy-making institutions - is 'plausible'. Functional pressures must be seen to be compelling. In this respect, elites act as agents selling necessity, urgency, compulsion and translating pressures into something persuasive by flagging up issue salience, interdependence and constraint (Niemann and 
Schmitter 2009: 57). In short, there is no automacity to the expansive logic of integration, but rather much depends on purposive behaviour and communication.

Where spillover does not occur, 'latent spillover pressure' may build up. There may be failure over time to secure the entrance of an issue onto the higher echelons of the policy agenda - perhaps due to unconvincing perceptions of the issue, or weak institutions - but successful spillover in other sectors. An analogy would be a reservoir that fills up creating pressure on the dam walls. Given exogenous factors, including changes in the economic climate or wider integration project, functional spillover pressure for action may be pent up, even increasing, until released - though such release is not guaranteed.

\section{TOWARDS A COMBINED FRAMEWORK FOR ANALYSING AGENDA-SETTING OVER TIME?}

Neofunctionalist spillover can add value to public policy concepts such as 'image' and 'venue' because of its emphasis on 'perception' and 'structure', and vice versa. Both literatures recognize similar features of the process, but neofunctionalism's focus on elite behaviour implicitly suggests how - through consensus, learning and interest - images and venues might be used, i.e. they articulate and accommodate elite behaviour. Neofunctionalism is helpful in conceiving of a general build-up of pressure in a certain direction, while agenda-setting theory provides factors to explain the articulation of this pressure - two essential constructive elements or 'jigsaw pieces' that help illustrate how spillover is mediated; venues/images combine in a dynamic process of interaction and transformation to 'put flesh on spillover's bones'.

Policy actors with vested interests forge an impression that policy action is necessary. One might even go as far as to argue that latent spillover pressure only exists insofar as policy actors advocate taking further steps, having usually identified possibilities for action (pitched as solutions), i.e. venues and images are used to make decision-makers feel the pressure for new decisions. In so doing, even the projection of images and messages - the mere talk of action - may be considered a form of latent pressure, thus tempting or provoking incremental change in a desired direction.

Figure 2 offers a combined framework for conceiving of mediating factors in agenda-setting that marries Princen's (2011) typologies of agenda-setting strategies (in the double-lined box) - after Baumgartner and Jones's (1993) notions of venue and image - with Haas' $(1958,1970,1975)$ notion of neofunctionalist spillover. The framework might be conceived of metaphorically as a sandwich one made from two slices of spillover bread with a 'nutritious' filling of venues and images, i.e., as a dynamic by which venues and images mediate the build-up and potential release of latent pressures for policy integration, determining whether or not spillovers occur. It suggests that both venue/image strategies need to be timely and targeted: venue - conducive and appropriate; image - convincing 


\begin{tabular}{|c|c|c|c|c|c|c|}
\hline $\begin{array}{l}\text { Neofunct- } \\
\text { ionalist } \\
\text { spillover }\end{array}$ & \multicolumn{5}{|c|}{$\begin{array}{c}\text { Agenda-setting strategies } \\
\text { mediating (and intensifying) latent spillover pressures } \\
\text { over time }\end{array}$} & $\begin{array}{l}\text { Neofunct- } \\
\text { ionalist } \\
\text { spillover }\end{array}$ \\
\hline \multirow{4}{*}{$\begin{array}{l}\text { Previous } \\
\text { spillover } \\
+ \\
\text { latent } \\
\text { pressure } \\
\text { to } \\
\text { act on } \\
\text { other } \\
\text { policy- } \\
\text { related } \\
\text { issues } \\
\text { i.e. } \\
\text { towards } \\
\text { further } \\
\text { spillover }\end{array}$} & $\begin{array}{l}\text { Venue } \\
\text { strategy to } \\
\text { gain } \\
\text { attention } \\
\text { to issue: }\end{array}$ & $\begin{array}{l}\text { Mobilising } \\
\text { support } \\
\text {-shopping } \\
\text {-modification }\end{array}$ & \multirow{2}{*}{$\begin{array}{l}\text { Venue } \\
\text { strategies } \\
\text {-conducive } \\
\text {-appropriate } \\
\text {-timely } \\
\text {-targeted } \\
\text {...to influence } \\
\text { structure }\end{array}$} & yes & \multirow{2}{*}{$\begin{array}{l}\text { Positive } \\
\text { outcome; } \\
\text { access } \\
\text { to policy } \\
\text { agenda } \\
\end{array}$} & \multirow{2}{*}{$\begin{array}{l}\text { Potential } \\
\text { for } \\
\text { latent } \\
\text { pressure } \\
\text { to be } \\
\text { released } \\
= \\
\text { spillover } \\
+ \\
\text { policy } \\
\text { change }\end{array}$} \\
\hline & $\begin{array}{l}\text { Venue } \\
\text { strategy to } \\
\text { build } \\
\text { credibility } \\
\text { of issue: }\end{array}$ & $\begin{array}{l}\text { Building } \\
\text { capacity } \\
\text {-inside EU } \\
\text {-outside EU }\end{array}$ & & no & & \\
\hline & $\begin{array}{l}\text { Image/ } \\
\text { Frame } \\
\text { strategy to } \\
\text { gain } \\
\text { attention } \\
\text { to issue: }\end{array}$ & $\begin{array}{l}\text { Arousing } \\
\text { interest } \\
\text {-big words } \\
\text {-small steps }\end{array}$ & \multirow{2}{*}{$\begin{array}{l}\text { Image/frame } \\
\text { strategies } \\
\text {-convincing } \\
\text {-appealing } \\
\text {-timely } \\
\text {-targeted }\end{array}$} & \multirow{2}{*}{$\begin{array}{l}\text { yes } \\
\text { no }\end{array}$} & \multirow{2}{*}{$\begin{array}{l}\text { Negative } \\
\text { outcome; } \\
\text { nil or } \\
\text { minimal } \\
\text { access } \\
\text { to policy } \\
\text { agenda }\end{array}$} & \multirow{2}{*}{$\begin{array}{l}\text { No } \\
\text { potential } \\
\text { for latent } \\
\text { pressure } \\
\text { to be } \\
\text { released } \\
= \\
\text { no } \\
\text { spillover } \\
+ \\
\text { no } \\
\text { policy } \\
\text { change }\end{array}$} \\
\hline & $\begin{array}{l}\text { Image/ } \\
\text { Frame } \\
\text { strategy to } \\
\text { build } \\
\text { credibility } \\
\text { of issue: }\end{array}$ & $\begin{array}{l}\text { Claiming } \\
\text { authority } \\
\text {-link to } \\
\text { existing } \\
\text { policies } \\
\text {-identifying } \\
\text { common } \\
\text { ground }\end{array}$ & & & & \\
\hline
\end{tabular}

Figure 2 How venue and image mediate spillover

and appealing. It raises the question whether both a successful venue and image strategy are needed, or if one will suffice to secure an issue's access to the agenda? The two are interwoven, however, since agenda-setters produce images/frames and target venues simultaneously. Ipso facto, an issue's failure to climb up the policy agenda may be precisely because one of these two elements is unsatisfactory, i.e. for venues, when sufficient support is not mobilized or capacity built, and for images/frames when the necessary interest is not aroused or authority claimed convincingly.

A combination of effective image/venue strategies may secure faster access up the policy agenda, encouraging policy formulation and decision. However, agenda access is not tantamount to spillover; strictly speaking, only if issue 'entrance' leads to some form of decision (often usually legally binding commitment) for collective action does policy integration occur. In some cases, venue/ image strategies may succeed in securing access high up the policy agenda, but decisions may be stalled or blocked, and the issue hijacked by other policy entrepreneurs (Princen and Rhinard 2006: 1122). 


\section{CASE: THE 'ISSUE CAREER' OF EUROPEAN RAIL TRANSPORT}

\section{Neofunctionalist expectations}

The neofunctionalists would have expected the 'expansive logic of sector integration' (Haas 1958: 283) to apply to transport, extending supranational institutional capabilities for the co-ordinated development of pan-European rail infrastructure, and cementing the 'four freedoms' of movement of persons, goods and services, capital and labour. Policy integration in and between sectors implied partnerships between Commission actors, interest groups and national officials. Steel was the heart of EC industry, playing a key role in establishing the European institutions (Dudley and Richardson 1997). It was thus not inconceivable for integration to extend from coal and steel to railways, since these resources (literally) fuelled train operations. Transporting coal and steel across borders would also rely on interoperable trains, signalling and track; and policy-makers would recognize that policy integration could stimulate intra-Community trade.

Scholars such as Trench (1963), Caporaso (1970) and Button (1993) address early transport developments in the Common Market, while Abbati (1986), Whitelegg (1989, 1993), Hamilton, (1990), Ross (1994, 1998) and Tolley and Turton (1995) analyse the CTP. Nijkamp (1993) and Vickerman (1994) focus on high-speed rail development, while Stevens (2004) examines policymaking in EU transport. Johnson and Turner $(1997,2007)$ take a political economy perspective on trans-European networks (TENs) in transport, telecoms and energy.

\section{Issue initiation (1945-1957)}

\section{Venue-mobilizing support}

After the destruction of war there was little support mobilized for co-ordinated rail planning and, unsurprisingly, even resistance to the notion of foreign trains on domestic soil, hence an absence of venues and political mistrust of co-operation in pan-European transport. The European Coal and Steel Community (ECSC) (1951) sought to manage and control primary resources, not manufacture railways. The ECSC Treaty appealed to prevailing values in terms of establishing 'common bases for economic development', but focused on non-controversial, 'practical achievements' in the short-term. According to Milward (1984: 494) it was the ECSC's extra-nationality, rather than its supra-nationality which gave it its integrative potential, since functional tasks could be achieved in a forum outside of, but not necessarily above the nationstate. The Treaty's regulatory framework did abolish quantitative restrictions on coal and steel movement, such as import/export duties (Article 4).

\section{Venue-building capacity}

The United Nations Economic Commission for Europe (UN-ECE) (1947), with its inland transport committee, was the principal international institutional arena for rail until the founding of the European Conference of Ministers of 
Transport (ECMT) in 1953 and Organization for Economic Cooperation and Development in 1961. The ECMT met twice a year, publishing regular research reports on infrastructure improvement that encouraged the rational development of key inland rail links. The Community institutions - the High Authority in 1951 as the executive of the ECSC and its counterbalance, the Special Council of Ministers (the forerunner of the Council of Ministers), as well as the European Court of Justice (ECJ) and European Parliament, both in 1952 - were in their infancy, with significant internal capacity-building and inter-institutional relationships still to forge. UN-ECE later established ties with the European Economic Community (EEC) a decade later in 1957, particularly the Commission (Treaty of Rome Article 229).

\section{Image-arousing interest}

European states deepened their entrenched stances regarding transport regulation, ownership and financing, preoccupied with the replacement and repair of vital national rail infrastructures, and by 1949 Europe was 'back on its feet' thanks to initial high rates of investment in fixed capital (Milward 1984: 482). As Wallace et al. (1983: 58) claim, national infrastructures were rebuilt without any support for the development of appropriate cross-border communication channels; planning was in and about the national self-interest. National governments imposed licensing conditions, controlling competition and providing piecemeal investment in domestic railways (Button 1993: 222).

Why was transport included in The Treaty of Rome, alongside agriculture? Because the political imperative was to create a single market. Transport was seen as a key to enabling the free movement of goods, services, capital and labour. Article 75 of the Treaty of Rome (now Article 95 of the TFEU) formed the legal basis of the Common Transport Policy (CTP), stating inter alia that the Council shall 'lay down: common rules applicable to international transport' and 'the conditions under which non-resident carriers may operate', 'measures to improve transport safety' and 'any other appropriate provisions'. In short, if attention was drawn to the transport issue it was for a single market for services, to be achieved by opening up market access, but precluding any notion of developing a common network of international infrastructures.

\section{Image-claiming authority}

Authority lay not with political bodies but technical and sectoral ones, including organizations for maritime, air and rail transport, the most significant for terrestrial rail being the International Union of Railways (IUR), established in 1922 (Ross 1998: 46). There was ample technical and planning expertise but spread across myriad international bodies, all seeking to assert themselves as experts, but with no political powers. Community law supposedly provided that authority: the Treaty of Rome asserted that, subject to the provisions within, 'transport policy [...] shall continue to be governed by the laws or regulations of the individual member states, as shall measures relating to co-ordination and competition between different modes of transport or different routes' (ECSC 1952, 
Chapter 9, Article 70). Community objectives would be 'pursued by Member States within the framework of a CTP' (Article 74).

\section{Issue specification $(1958-1980)$}

\section{Venue-mobilizing support}

The Commission (1961) sought to mobilize the Community with a first action programme on transport. Such opportunistic issue promotion was constrained by the Council where unanimity was required. Only in 1976 did the Commission eventually establish a Committee for Transport Infrastructures (CTI), with a remit to consult member states in order to develop transport questions of 'Community interest' (Council 1978), including the creation of new links, removal of 'bottlenecks', increase in rail capacity and development of crossborder routes. It consulted the CTI before submitting three-yearly reports to the Council and EP (Johnson and Turner 1997: 9-12). A new venue was established with the European Investment Bank (EIB) in 1958 to loan funds to national governments to build infrastructures.

\section{Venue-building capacity}

The Council of Ministers adopted the CEMT's network plan in 1965, but minimal progress resulted due to an inability to translate proposals into concrete measures, a lack of internal consensus and the Commission's weak institutional power. DG Transport [VII], then an institutional backwater, reported to the EP's transport committee. It sought horizontal support from European railways bodies - networks of professionals with recognized competences in rail planning. Only in 1978 did the EP finally express concern over Council foot-dragging on a CTP (Hamilton 1990: 16). DG Transport began building up its informational resources, drawing on research produced by a burgeoning epistemic community of rail experts and academics, including CEMT and UN-ECE. From the early 1970s, the IUR developed its own permutations of a crossborder rail network with a range of investment scenarios - a bold vision offering a blueprint for a pan-European rail network.

\section{Image-arousing interest}

The inauguration of the Trans European Express (Europe's first inter-city rail services) captured the imagination in 1957 by introducing interoperable rolling stock, and consequently much attention was paid in the first decade of the EEC to deregulating freight and passenger services. At the outset of the EEC, the farming lobby aroused huge political and social interest with its emotive appeals to ensure basic food supply and prevent hunger. With its human dimension, agriculture was perceived as 'urgent'. Rail transport had to compete for interest but also cope with its perceived image as complex and highly technical; it would remain isolated, sealed off or 'encapsulated' within Community policymaking for another decade (Caporaso 1970: 366). 
Member States showed scant interest in the Schaus Memorandum, which presented first guidelines for a Community-wide action programme in transport (Commission 1961; Giorgi and Schmidt 2002), but steps towards co-ordinated rail construction were approved in 1969, obliging member states to provide technical route descriptions, expenditure estimates and work schedules (Johnson and Turner 1997: 7). Political interest was nonetheless weak; the CEMT/Commission's 1974 blueprint for a network of rail arteries, to be expanded as the Community developed, was ignored in Council committees (COM(73)1725 final). Decisions were overturned while meetings failed to address wider, long-term issues (Wallace et al. 1983: 403-24). Transport Policy (CTP) remained patchy, incremental and sporadic. The common political interest was to pursue national policies and 'keep transport down'.

The Commission tried to arouse the member states' interest by repeatedly presenting 'packages' of proposals in the hope of reaching compromise in the Council through mutual concessions. Practically speaking, it was left to monitor national rail investment priorities, consult member states widely and fine parties who refused to disclose national transport rules. As Stevens (2004: 54) asserts, the Dutch Presidency in the first half of 1981 saw so little point in the many proposals, and so little prospect of making any progress towards the type of transport policy it sought, that it actually cancelled both Council meetings in the first half of 1981.

\section{Image-claiming authority}

While EEC members had signed up to a common market, in no explicit terms did they perceive rail as an instrument for market integration. The Treaty referred opaquely to the 'distinctive features of transport' (Article 75). Transport was a 'secondary' sector, dragged forward incrementally to keep up with lowest common policy advances in other sectors (Caporaso 1970: 370). Why exactly? Ross (1998: 45) claims that the Treaty's 'innocuous' wording shrouded the obvious functional link between transport and market integration. Purposeful ambiguity undermined subsequent Commission attempts to set the agenda for transport infrastructure (Trench 1963) - it still lacked the policy-making authority. What was missing was the effective issue linkage with economic growth and regional development. By the late 1970s, the CTP - which ignored infrastructure completely - was 'an ineffective policy, pursued in an indifferent manner, based on simplistic economic notions' (Tolley and Turton 1995; Whitelegg 1989, 1993). In the late 1970s, the Commission urged the provision of vital Community aid to fund rail construction projects, to guard against long-term losses in the integration process $(\mathrm{COM}(79) 550$ final).

\section{Issue expansion (1981-1988)}

\section{Venue-mobilizing support}

Finally, in March 1981 the Council backed a Commission proposal for infrastructure investment to facilitate cross-border movements (Council 1981; 
Hamilton 1990: 16). But in 1983, in an unprecedented action, the EP took the Council to the ECJ for failure to deliver a CTP; the deadline, as laid down in the Treaty, had been December 1969. The May 1985 judgement on Case 13/83 ruled that, although original references to the CTP in the Treaty were vague, it had nonetheless been infringed. This supranational legal venue was crucial for forging political support in the Council, giving the Commission room to manoeuvre. In terms of venues, this was an 'inside initiative' insofar as it was internal to the process, and was deliberately brought about by one of the EC's institutional actors. Why did the EP decide to go to the ECJ, and why at this time? With direct elections in 1979, the EP was seeking to flex its muscle - it was frustrated and lacked influence, 'casting about for a means to break the logjam' (Stevens 2004: 54-5). The constellation of actors was propitious: in the summer of 1981 there was a new Director-General of Transport (Steele), while the Parliament's rapporteur and his relevant director in the Commission were both Italian (common culture and language); hence DG Transport persuaded the EP to focus its attack on the Council (Stevens 2004: 55). At a Council meeting soon after the judgement, the German Minister appealed to colleagues, insisting that never again should they be condemned in such a way (Héritier and Knill 2001: 53; in Stevens 2004: 55-6).

Moreover, by this time the European business community was well mobilized. In 1985, 471 out of 654 Brussels-based interest associations were industry-related or commerce-oriented (Streeck and Schmitter 1991: 137). European technology had producers and consumers formed unified, pan-European pressure groups. The Commission became the 'arbiter' of varied, conflicting, yet converging interests (Ross 1998: 28). The European Round Table of Industrialists (ERT), established in 1983, exerted a crucial influence and showed 'outside initiative': some $45 \mathrm{CEOs}$ from large European firms, including high-speed train constructors and rail operators, grabbed the attention of political actors, stressing the Community's (potentially adverse) economic future, if no action were taken in the countdown to '1992'. Support was also sought from new venues: the Community of European Railways (1988) emerged as an independent group of the IUR, which, with the Union of European Railway Industries, began to organize the Eurailspeed congress - landmark occasions for the European rail industry and policy-making technocrats to mobilize, socialize and strengthen.

\section{Venue-building capacity}

Inside the EC institutions, the renewed confidence of DGs Transport (DGVII), Energy (DGXVII) and Telecommunications (DGXIII) (Whitelegg 1993: 157) initiated policy proposals. The Commission was entrepreneurial in pushing trans-national rail issues and increasingly successful at getting technology proposals (for example, the 4th and 5th Framework Programmes) adopted by the Council (Schneider et al. 1994: 475). This was done by internal re-organization and through strong leadership. Jacques Delors, Commission President from January 1985, fervently supported greater liberalization and harmonization, 
competition and non-discrimination. As Ross (1994: 193) asserts '..."his" Commission assumed a much more activist stance on high-speed rail planning, development and funding'. For further insight into Commission entrepreneurship in this area, see Stephenson (2010).

\section{Image-arousing interest}

Delors referred to the need for 'thinking big' and being 'far-sighted' while 'taking account of world-wide geopolitical and economic trends' (Delors 1988, 1989). The Commission became more convincing in its language and developed a better technical grasp of the 'multiplicity of issues involved, and had no lack of ideas about how to tackle them' (Ross 1998: 53), heeding to calls by Brussels-based industry to liberalize, deregulate and abolish barriers the Kangaroo Club of 1981 had desired to 'hop over barriers' to secure trade gains. This was echoed in the business community's own publications, which used the analogy of 'missing links' to argue for new rail infrastructures within EC transport policy (ERT 1984, 1986, 1987, 1989, 1991). The European Roundtable of Industrialists (ERT) lobby recognized 'inefficiencies in the decision-making process' (complexity, insufficient participation and postponement) and an 'ineffective planning process' (lack of a system approach and lack of a European-level body) as barriers to issue expansion (Umbach 1990: 28-30). In 1986, the Commission sought to attract interest in a mediumterm vision for high-speed rail, aimed at boosting competitiveness $(\operatorname{COM}(86) 340$ final), just as Spain and Portugal's accession focused attention on the issue, given significant disparities in infrastructural provision and the existence of different rail gauge widths.

\section{Image-claiming authority}

The timing of the ECJ's decision, on the eve of the SEA, was crucial for 'economicizing' rail transport towards competition and internal market. The Commission learnt to convey the trans-national nature of Community transport better. The explicit link to infrastructure development gave the CTP a spatial/structural dimension. As Ross (1998: xii) maintains, transport became horizontally integrated with other policy areas - regional policy, environment, competition, energy, enlargement, budget, $R \& D$ and information society: 'it had its finger in nearly every EU pie'. Through policy synergies, transport emerged as 'a fulcrum around which other policy areas increasingly revolved[d], both functionally and in a policymaking sense' (Ross 1998: 11-12). The 1984 white paper (Cockfield report) recognized physical and technical barriers to integration, yet its proposals were fiscal and concerned cross-border business and tax harmonization - co-ordinated infrastructure planning was not deemed 'an essential element' $(\mathrm{COM}(85) 310$, paragraph 112). But the 1988 Cecchini report, predicting a one-off net increase in total EC growth of 5 per cent by removing market obstacles (SEC(88)524 final), did later give an intellectual authority to arguments that transport-related ills threatened market 
integration, justifying DG Transport's (VII) proposal for an action programme for rail infrastructure investment $(\operatorname{COM}(88) 340)$.

\section{Issue entrance (1989-1996)}

Venue-mobilizing support

Calling for a Transport Infrastructure Policy ((COM(89)238); Community of European Railways 1989), and 'Community Action Programme' $(\operatorname{COM}(90) 585)$ for TENs, the Commission headed up a new institutional arena - a high-level working group, composed of member state representatives and led by commissioners for transport (Kinnock) and internal market (Christophersen) (High-Level Group on TENs 1990). Rail transport issues began attracting more political attention at European summits (Edinburgh, December 1992; Copenhagen, June 1993), eventually securing political decisions (Corfu, June 1994; Essen, December 1994).

\section{Venue-building capacity}

Following a 'Declaration of European Interest' to help establish TENs $(\operatorname{COM}(92) 15)$ - subsequently given legal status at Maastricht (Article 129bd TEU, now Articles 170-172 TFEU), the Commission looked to the future, building capacity for implementation by creating a separate TEN-T budget, financial regulation (1995) and guidelines for member states (1996). It worked closely with the EIB on loan provision - experimenting with private-public partnerships relatively unsuccessfully (Turró 1999) - and used new information technology to improve data exchange, communication with, and monitoring of, national transport ministries.

\section{Image-arousing interest}

Liberalizing rail transport implied harmonizing traffic management systems, ensuring technical 'interoperability' and promoting non-discrimination; infrastructure owners across Europe could no longer deny access to non-national rail operators (Directive 91/400). TENs was embedded within the policy discourse of '1992', highlighting the causal relationship between infrastructure investment, and growth and employment (COM(93)700 final). Hence, the pursuit of co-ordinated rail investment was framed using the body metaphor, with high-speed rail lines as the 'backbone' and conventional, secondary routes as the 'arteries'.

\section{Image-claiming authority}

As Schneider et al. (1994: 474) assert, by the early 1990s the European institutions could no longer be described as 'passive social environments' but as 'active components with autonomous action capabilities', as the neofunctionalists would expect. The Commission's DG Transport and DG Internal Market had evolved into authoritative bodies able to reconcile multiple interests and highlight successively European rail transport's link to medium-term political priorities. Figure 3 provides an 'at-a-glance' overview of European rail transport's issue career. 
The four-stage issue career might be considered: overlooked, suppressed, entwined and liberated. The rail transport issue showed a long period of specification followed by a relative short period of expansion when venues and images proved crucial. In terms of the dynamics for agenda-setting change, Community rail transport 'jumped' the Single Market train - '1992' was the 'issue engine' carrying it up the political agenda. The period between the third and fourth stage of the issue's career - expansion and issue entrance was crucial. Venues and images were finally strong enough to mediate the latent pressures that had built up (or at least, had been projected to have done so). Considerable support had been mobilized, adequate capacity built, sufficient interest aroused; policy proponents could claim sufficient authority and gain the attention of policy-makers. Timing and sequences were important;

\begin{tabular}{|c|c|c|c|c|}
\hline & \multicolumn{2}{|l|}{ Venue } & \multicolumn{2}{|l|}{ Image } \\
\hline $\begin{array}{l}\text { Career } \\
\text { stage / Time }\end{array}$ & $\begin{array}{l}\text { Mobilising } \\
\text { support }\end{array}$ & $\begin{array}{l}\text { Capacity } \\
\text { building }\end{array}$ & $\begin{array}{l}\text { Arousing } \\
\text { interest }\end{array}$ & $\begin{array}{l}\text { Claiming } \\
\text { authority }\end{array}$ \\
\hline Aim & Gain attention & Build credibility & Gain attention & Build credibility \\
\hline $\begin{array}{l}\text { Issue } \\
\text { initiation } \\
\text { 1945-1957 }\end{array}$ & $\begin{array}{l}\text { Low } \\
\text { CAP dominates; } \\
\text { Transport sector } \\
\text { not mobilised; } \\
\text { low international } \\
\text { rail traffic }\end{array}$ & $\begin{array}{l}\text { Low } \\
\text { High Authority of } \\
\text { ECSC in its } \\
\text { infancy with low } \\
\text { level of expertise; } \\
\text { ECMT new venue }\end{array}$ & $\begin{array}{l}\text { Low } \\
\text { Nation states } \\
\text { rebuilt domestic } \\
\text { rail networks; no } \\
\text { political support } \\
\text { for joint planning }\end{array}$ & $\begin{array}{l}\text { Low } \\
\text { Authority with } \\
\text { technical and } \\
\text { sectoral bodies } \\
\text { who had no } \\
\text { political powers }\end{array}$ \\
\hline \multicolumn{5}{|c|}{ LOW SPILLOVER PRESSURE $\rightarrow$ NO AGENDA-SETTING CHANGE } \\
\hline $\begin{array}{l}\text { Issue } \\
\text { specification } \\
1958-1980\end{array}$ & $\begin{array}{l}\text { Medium } \\
\text { Treaty status but } \\
\text { Council impedes } \\
\text { much progress } \\
\text { EP concerned; } \\
\text { Commission sets } \\
\text { up infrastructure } \\
\text { committee }\end{array}$ & $\begin{array}{l}\text { Low } \\
\text { Commission } \\
\text { has weak power } \\
\text { but courts experts, } \\
\text { collects data as } \\
\text { Council foot- } \\
\text { drags on CTP; } \\
\text { EIB new venue }\end{array}$ & $\begin{array}{l}\text { Medium } \\
\text { Rail technical } \\
\text { and complex, } \\
\text { CEMT blueprint } \\
\text { ignored by } \\
\text { Council which } \\
\text { had no long-term } \\
\text { vision }\end{array}$ & $\begin{array}{l}\text { Low } \\
\text { Link between } \\
\text { transport and } \\
\text { market } \\
\text { integration } \\
\text { ambiguous; } \\
\text { incremental } \\
\text { advances }\end{array}$ \\
\hline \multicolumn{5}{|c|}{ LOW-MEDIUM SPILLOVER PRESSURE $\rightarrow$ NO AGENDA-SETTING CHANGE } \\
\hline $\begin{array}{l}\text { Issue } \\
\text { expansion } \\
1981-1988\end{array}$ & $\begin{array}{l}\text { High } \\
\text { Council backs } \\
\text { infrastructure; } \\
\text { ECJ empowers } \\
\text { DG Transport; } \\
\text { business interests } \\
\text { mobilised }\end{array}$ & $\begin{array}{l}\text { Medium } \\
\text { Renewed } \\
\text { Commission } \\
\text { confidence; CTP } \\
\text { revived; } \\
\text { CER new venue; } \\
\text { UNIFE active }\end{array}$ & $\begin{array}{l}\text { High } \\
\text { Better use of } \\
\text { language and } \\
\text { ideas; good } \\
\text { technical grasp; } \\
\text { ambitious } \\
\text { proposals }\end{array}$ & $\begin{array}{l}\text { Medium } \\
\text { Rail transport } \\
\text { 'economicized'; } \\
\text { Solution to jobs } \\
\text { and growth threat } \\
\text { infrastructure } \\
\text { investment }\end{array}$ \\
\hline \multicolumn{5}{|c|}{ MEDIUM-HIGH SPILLOVER PRESSURE $\rightarrow$ AGENDA-SETTING CHANGE } \\
\hline $\begin{array}{l}\text { Issue } \\
\text { entrance } \\
1989-1996\end{array}$ & $\begin{array}{l}\text { High } \\
\text { High-Level } \\
\text { Group reports to } \\
\text { 1994 European } \\
\text { Council; package } \\
\text { deal agreed by } \\
\text { member states }\end{array}$ & $\begin{array}{l}\text { High } \\
\text { Maastricht Treaty } \\
\text { gives legal basis; } \\
\text { Commission } \\
\text { develops policy } \\
\text { tools to encourage } \\
\text { member states }\end{array}$ & $\begin{array}{l}\text { High } \\
\text { High-speed rail } \\
\text { dynamic within } \\
\text { 'TENs'; network } \\
\text { of infrastructures } \\
\text { vital for market } \\
\text { integration }\end{array}$ & $\begin{array}{l}\text { High } \\
\text { Commission } \\
\text { possesses } \\
\text { expertise; uses } \\
\text { research to } \\
\text { forecast growth } \\
\text { and jobs benefits }\end{array}$ \\
\hline \multicolumn{5}{|c|}{ GH SPILLOVER PRESSURE $\rightarrow$ AGENDA-SETTING CHANGE } \\
\hline
\end{tabular}

Figure 3 Empirical realities: the issue career of European rail infrastructure 
the likelihood of spillover in the late 1980s was conditioned by the extent of previous policy expansion, itself partly explained by the degree of competition from other sectors for issue attention, i.e. the long-term failure of the CTP versus considerable functional and political spillover in agriculture. Thus, an issue's career must be understood vis- $\grave{a}$-vis the issue careers of other policy fields; an issue can 'simmer' for decades as the hobbyhorse of technocrats, experts and sectoral bodies, 'specified' and 'expanded' low down the agenda, only rising up when the combination of venue and image is conducive.

\section{CONCLUSION}

From a public policy perspective the combined framework developed and applied in this article enables a more insightful and precise explanation of how agenda-setting, as articulated through the use of venues and images (Baumgartner and Jones 1993), can be situated temporally as part of an actor-driven integration process (Haas 1958). From a European integration studies perspective, it brings a new understanding to the mechanics behind the dynamics of neofunctionalist spillover by, first, considering integration as 'fed' by the cumulative build-up of incidences of agenda-setting change, and second, accepting that the translation/communication of issues into successful calls for collective policy action depends on perceptions and structures. This is particularly useful because it offers a practical, systematic and nuanced way to identify how integration is stimulated (or not) through the lifecycle of issues.

Marrying these concepts in an experimental way offers a means to examine an issue's trajectory upwards onto the agenda of Community policy-makers over time. It helps show that, even beyond the heyday of neofunctionalism, the spillover concept remains highly relevant for the study of contemporary policymaking, since day-to-day it is via venues and images that institutions learn to transfer loyalties, shape beliefs, establish linkages and legitimise authority, all central to Haas' premises. Moreover, the notion that venues and images are shopped for and crafted by elites relates directly to the neofunctionalist recognition of elite creativity, entrepreneurship and interest mobilization, as well as the incremental nature of the process - agenda-setting (and integration) is dependent on concerted and multifarious action over time.

If venue and image are each important for gaining issue attention and building issue credibility, is one more crucial than the other when it comes to securing agenda-setting change? The two are difficult to separate, since venues possess their own institutional images, either purposively manufactured or purely by association, owing to the general perception of the issue - as exciting, dull, boring, complex, etc. Moreover, some venues help lay the 'groundwork' for change, sustaining pressure and momentum in the policy subsystem through the provision of information, ideas and appeals, which are then used by other venues in conducive, targeted and creative ways. In short, without venue there is no support or capacity for elites; without image, elites have no authority and cannot secure the interest of policy-makers. If communication fails, there is 
no cognitive processing of the notion that further collective (integrative) action is desirable.

Analyses of agenda-setting in the EU can benefit from longitudinal microstudies of venue and image strategies. The new status given to the European Council as agenda-setter, as well as national parliamentary scrutiny and civil society groups post-Lisbon, bring new dynamics to the study of agendasetting change, in terms of the interest, authority, support and capacity of multi-level actors in the EU policy process.

Biographical note: Paul Stephenson is Assistant Professor at the Department of Politics, Maastricht University.

Address for correspondence: Paul J. Stephenson, Faculty of Arts and Social Sciences, Maastricht University, PO Box 616, 6200 MD Maastricht, The Netherlands. email: p.stephenson@maastrichtuniversity.nl

\section{ACKNOWLEDGEMENTS}

The author thanks three anonymous reviewers for their constructive criticism, and is grateful to Sebastiaan Princen, who positively encouraged reorienting a previous draft towards a reconciliation of the two literatures. Figure 1 draws on grids originally featuring in an earlier version of his 2011 JEPP article.

\section{REFERENCES}

Baumgartner, F. and Jones, B. (1991) 'Agenda dynamics and policy subsystems', Journal of Politics 53(4): 1044-74.

Baumgartner, F. and Jones, B. (1993) Agendas and Instability in American Politics, Chicago: University of Chicago Press.

Baumgartner, F. and Jones, B. (eds) (2002) Policy Dynamics, Chicago: University of Chicago Press.

Button, K. (1993) Transport Economics, Aldershot: Edward Elgar.

Caporaso, J. (1970) 'Encapsulated integrative patterns vs. spillover: the cases of agricultural and transport integration in the European Economic Community', International Studies Quarterly 14(4): 361-94.

Caporaso, J. and Keeler, J. (1995) 'The European union and regional integration theory', in S. Mazey and C. Rhodes (eds), Building a European Policy, Boulder, CO: Lynne Rienner, pp. 29-62.

Cobb, R., Ross, J. and Ross, M. (1976) 'Agenda building as a comparative political process', American Political Science Review 70(1): 126-38.

Commission (1961) Schaus Memorandum on the General Lines of the Common Transport Policy, submitted to the Council, 10 April 1961.

Community of European Railways (1989) Proposals for a European high-speed network, Brussels.

Council (1978) 'Decision 78/174/EEC of 20 February 1978 instituting a consultation procedure and setting up a Committee in the field of Transport Infrastructure', Brussels.

Council (1981) 'Resolution of 15 December 1981 on Community railway policy', Brussels. 


\section{4}

Journal of European Public Policy

degli Abbati, C. (1986) Transport and European Integration, Brussels: Commission of the European Communities.

Delors, J. (1988) Speech entitled 'A family of nations', College of Europe, Bruges, 20 September.

Delors, J. (1989) Speech entitled, 'A necessary union', College of Europe, Bruges, 17 October.

Downs, A. (1972) 'Up and down with ecology - the 'issue-attention cycle', The Public Interest 28: 38-50.

Dudley, G. and Richardson, J. (1997) 'Competing policy frames in EU policy making: the rise of free market ideas in EU steel policy 1985-1996', European Integration online Papers (EIoP) 1: 13.

ERT (1984) 'Missing links', Brussels: European Round Table of Industrialists, December.

ERT (1986) 'Promoting and Financing Large-Sale Infrastructure Projects in Europe', report jointly prepared by the European Round Table of Industrialists and the European Commission, Brussels, February.

ERT (1987) 'Keeping Europe mobile', Brussels: European Round Table of Industrialists, December.

ERT (1989) 'The need for renewing transport infrastructure in Europe', Brussels: European Round Table of Industrialists.

ERT (1991) 'Missing networks', Brussels: European Round Table of Industrialists.

Farrell, H. and Héritier, A. (2005) 'A rationalist-institutionalist explanation of endogenous regional integration', Journal of European Public Policy 12(2): 273-90.

Giorgi, L. and Schmidt, M. (2002) 'European transport policy - a historical and forward looking perspective', German Policy Studies/Politikfeldanalyse 2(4): 1-19.

Green-Pedersen, C. and Wilkerson, J. (2006) 'How agenda-setting attributes shape politics: basic dilemmas, problem attention and health politics developments in Denmark and the US', Journal of European Public Policy 13(7): 1039-52.

Haas, E. (1958) Uniting of Europe - Political, Economic and Social Forces 1950-1957, Stanford, CA: Stanford University Press;, reprinted by UMI Books on Demand, Michigan 1997.

Haas, E. (1970) 'The study of regional integration: reflections on the joy and anguish of pretheorizing', International Organization 24(4): 607-46.

Haas, E. (1975) The Obsolescence of Regional Integration Theory, Berkeley, CA: University of California Press.

Hamilton, K. (1990) Transport Policy - Spicer European Policy Reports, London: Routledge.

Héritier, A. and Knill, C. (2001) 'Differential responses to European policies: a comparison', in A. Héritier et al. (eds), Differential Europe. The European Union Impact on National Policy-Making, Lanham, MD: Rowman \& Littlefield, pp. 257-94.

High-Level Group on TENs (1990) Report on the Development of a European high-Speed Rail Network, summary report of the group, December 1990.

Hogwood, B. and Gunn, L. (1984) Policy Analysis for the Real World, Oxford: Oxford University Press.

Johnson, D. and Turner, C. (1997) Trans-European Networks - The Political Economy of Integrating Europe's Infrastructure, London: Macmillan.

Johnson, D. and Turner, C. (2007) Strategy and Policy for Trans-European Networks, Basingstoke: Palgrave Macmillan.

Kingdon, J. (1984) Agendas, Alternatives and Public Policy, Boston, MA: Little Brown.

Lindberg, L. (1963) Political Dynamics of European Economic Integration, Stanford, CA: Stanford University Press; reprinted by UMI Books on Demand, Michigan 1997.

Lindberg, L. (1965) 'Decision-making and integration in the European Community', International Organization 19(1): 56-80. 
Milward, A. (1984) The Reconstruction of Western Europe, 1945-51, London: Routledge.

Niemann, A. and Schmitter, P. (2009) 'Neofunctionalism', in A. Wiener and T. Diez (eds), European Integration Theory, 2nd edn, Oxford: Oxford University Press, pp. 45-66.

Nijkamp, P. (1993) Europe on the Move, Aldershot: Avery.

Peters, B. (1996) 'Agenda-setting in the European Union', in J. Richardson (ed.), European Union: Power and Policy-Making, London: Routledge, pp. 77-94.

Peterson, J. (1991) 'Technology policy in Europe: explaining the framework programme and Eureka in theory and practice', Journal of Common Market Studies 29(3): 269-90.

Pollack, M. (1997) 'Delegation, agency and agenda-setting in the European Community', International Organization 51(1): 99-134.

Pralle, S. (2006) 'Timing and sequence in agenda-setting and policy change: a comparative study of lawn care pesticide politics in Canada and the US', Journal of European Public Policy 13(7): 987-1005.

Princen, S. (2007) 'Agenda-setting in the European Union: a theoretical exploration and agenda for research', Journal of European Public Policy 10(1): 21-38.

Princen, S. (2009) Agenda-setting in the European Union, Basingstoke: Palgrave Macmillan.

Princen, S. (2010) 'Venue shifts and policy change in EU fisheries policy', Marine Policy 34(1): 36-41.

Princen, S. (2011) 'Agenda-setting strategies in EU policy processes', Journal of European Public Policy, DOI: 10.1080/13501763.2011.599960.

Princen, S. and Rhinard, M. (2006) 'Crashing and creeping: agenda-setting dynamics in the European Union', Journal of European Public Policy 13(7): 1119-32.

Ross, J. (1994) 'High-speed rail: catalyst for European integration?', Journal of Common Market Studies 32(2): 191-214.

Ross, J. (1998) Linking Europe: Transport Policies and Politics in the EU, London: Praeger.

Schmitter, P. (1969) 'Three neo-functional hypotheses about international integration', International Organization 23(0): 233-71.

Schmitter, P. (1970) 'A revised theory of regional integration', International Organization 24(4): 836-68.

Schneider, G. (1991) Time, Planning and Policy-Making: An Evaluation of a Complex Relationship, Berne: European Academic Publishers.

Schneider, V., Dang-Nguyen, G. and Werle, R. (1994) 'Corporate actor networks in European policy-making: harmonizing telecommunications policy', Journal of Common Market Studies 32(4): 473-98.

Stephenson, P. (2010) 'Let's get physical: the Commission and cultivated spillover in completing the Single Market's transport infrastructure', Journal of European Public Policy 17(7): 1039-57.

Stevens, H. (2004) Transport Policy in the European Union, Basingstoke: Palgrave Macmillan.

Streeck, W. and Schmitter, P. (1991) 'From national corporatism to transnational pluralism: organized interests in the single European market', Politics and Society 19(2): 133-64.

Tolley, R. and Turton, B. (1995) Transport Systems, Policy and Planning - A Geographical Approach, Harlow: Longman.

Trench, S. (1963) 'Transport in the common market', Planning 29, 8 July.

Turró, M. (1999) Going Trans-European - Planning and Financing Transport Networks for Europe, London: Pergamon.

Umbach, R. (1990) Paper addressed to the Centre for European Policy Studies, Brussels, 25 September 1990. 


\section{Journal of European Public Policy}

Vickerman, R. (1994) 'Transport infrastructure and regional building in the European community', Journal of Common Market Studies 32(1): 1-24.

Wallace, H., Wallace, W. and Webb, C. (1983) Policy-Making in the European Community, London: John Wiley \& Sons Ltd.

Whitelegg, J. (1989) Transport Policy in the European Economic Community, London: Routledge.

Whitelegg, J. (1993) Transport for a Sustainable Future: The Case for Europe, London: John Wiley and Sons Ltd. 